\title{
Minute Times Mole Per Liter Per Gram
}

National Cancer Institute

\section{Source}

National Cancer Institute. Minute Times Mole Per Liter Per Gram. NCI Thesaurus. Code C112346.

Minutes times moles per liter, divided by grams. 